\title{
Insulin Attenuates Vasopressin-induced Calcium Transients and a Voltage- dependent Calcium Response in Rat Vascular Smooth Muscle Cells
}

Paul R. Standley, ${ }^{* * 8}$ Feng Zhang, ${ }^{*}$ Jeffrey L. Ram, ${ }^{* *}$ Michael B. Zemel, ${ }^{* \| 1}$ and James R. Sowers***

Department of ${ }^{*}$ Physiology, and the ${ }^{\ddagger}$ Division of Endocrinology and Hypertension, Wayne State University, Detroit, Michigan 48201;

${ }^{8}$ Veterans Administration Medical Center, Allen Park, Michigan 48101; and the "University of Tennessee, Knoxville, Tennessee 37996

\begin{abstract}
Insulin attenuates the contractile responses of vascular smooth muscle (VSM) to various agonists. Insulinopenic and insulinresistant rats lack this normal attenuation of vascular contractile responses. To study this attenuating mechanism, the effects of insulin on calcium $\left(\mathrm{Ca}^{2+}\right)$ responses of cultured VSM cells (a7r5) to arginine vasopressin (AVP) and membrane potential were investigated. Insulin (1 and $100 \mathrm{mU} / \mathrm{ml}$ ) shifted AVP dose-response curves to the right, reducing relative potency of AVP by 16-fold and 220-fold, respectively. Responses to AVP were significantly attenuated within $30 \mathrm{~min}$ of insulin application. The AVP-elicited rise in $\left[\mathrm{Ca}^{2+}\right]_{i}$ was partially dependent upon extracellular $\mathrm{Ca}^{2+}$. AVP-elicited inward current was reduced by $90 \mathrm{~min}$ of insulin treatment $(100 \mathrm{mU} / \mathrm{ml})$, from a peak current of $-103 \pm 27 \mathrm{pA}$ (normal) to $-37 \pm 15 \mathrm{pA}$ (insulin treated). Peak voltage-dependent $\mathrm{Ca}^{2+}$-dependent inward current was unaffected by insulin; however, the current-voltage curve was shifted $16 \pm 3 \mathrm{mV}$ to the right by insulin. Thus, insulin may reduce VSM contractile responses by attenuating agonistmediated rises in $\left.\mathrm{Ca}^{2+}\right]_{\mathrm{i}}$ mediated, in part, by reductions in $\mathrm{Ca}^{2+}$ influx through both receptor- and voltage-operated channels. (J. Clin. Invest. 1991. 88:1230-1236.) Key words: diabetes; hypertension • fura- 2 whole cell recording
\end{abstract}

\section{Introduction}

Recent observations have suggested that impaired cellular responses to insulin are associated with increased vascular smooth muscle (VSM) ${ }^{1}$ tone (1-4), the hallmark of the hypertensive state in both type I and type II diabetes (4-6). Recently reported studies demonstrated that insulin, in physiological doses, shifted the $\mathrm{ED}_{50}$ for vascular contractile responses to phenylephrine and serotonin to higher concentrations without changing the maximum response (7). Similarly, insulin attenuated vasoconstrictive responses to norepinephrine and angiotensin II in rabbit femoral artery and vein (8). Furthermore,

A preliminary report of this work has been published in abstract form in 1991 (J. Cell. Biochem. [Suppl.15C]:115).

Address reprint requests to Dr. Jeffrey L. Ram, Department of Physiology, Wayne State University, Detroit, MI 48201.

Received for publication 5 November 1990 and in revised form 11 June 1991.

1. Abbreviations used in this paper: MANOVA, measures analysis of variance; PSS, physiological salt solution; VSM, vascular smooth muscle; VSMC, VSM cells.

J. Clin. Invest.

(C) The American Society for Clinical Investigation, Inc.

0021-9738/91/10/1230/07 $\$ 2.00$

Volume 88, October 1991, 1230-1236 vessels from both insulinopenic (9) and insulin-resistant rats (7, 10) demonstrated enhanced vasoconstrictive responses to various agonists. Although maximal vasoconstrictive responses of isolated vessels to agonists were the same in insulinresistant and normal rats, the $\mathrm{ED}_{50}$ for responses to phenylephrine, serotonin, and potassium chloride were shifted to lower concentrations in vessels from insulin-resistant rats (7). Thus, insulin appears to attenuate the vascular contractile response to both receptor and voltage-dependent mechanisms.

Calcium $\left(\mathrm{Ca}^{2+}\right)$ is generally acknowledged to be important in mediating VSM contractile responses (11). Insulin could accordingly attenuate VSM contractility by altering movement of $\mathrm{Ca}^{2+}$ into VSM cells or by affecting intracellular release of $\mathrm{Ca}^{2+}$ from storage sites. Indeed, in skeletal muscle, insulin has been demonstrated to produce hyperpolarization, to reduce $\mathrm{Ca}^{2+}$ currents, and to shorten $\mathrm{Ca}^{2+}$-mediated action potentials (12), and in VSM tissue insulin regulates $\mathrm{Ca}^{2+}$ efflux (13). Our study was designed to examine the effects of insulin on both agonist and voltage-mediated $\mathrm{Ca}^{2+}$ responses in cultured VSM cells (VSMC).

\section{Methods}

Preparation of VSMC. A7r5 VSMC (derived from embryonic DB1X rat thoraic aorta) were obtained from American Type Culture Collection, Rockville, MD. Cells were maintained under $5 \% \mathrm{CO}_{2}$ and $100 \%$ humidity at $37^{\circ} \mathrm{C}$ in growth medium (DMEM supplemented with $9 \%$ fetal bovine serum [FBS], $0.2 \%$ Tylosin, $100 \mathrm{U} / \mathrm{ml}$ penicillin, and 0.1 $\mathrm{mg} / \mathrm{ml}$ streptomycin). Serial passages were obtained by treating confluent cultures with $0.2 \%$ trypsin, $1 \mathrm{mM}$ EGTA in $\mathrm{Ca}^{2+} / \mathrm{Mg}^{2+}$-free HBSS (Sigma Chemical Co., St. Louis, MO) for $10 \mathrm{~min}$ at $37^{\circ} \mathrm{C}$. Released cells were centrifuged at 1,200 rpm for $5 \mathrm{~min}$, and the cell pellet was then resuspended in DMEM.

For VSMC $\mathrm{Ca}^{2+}$ studies, confluent cells were plated onto glass cover slips $(13 \times 50 \mathrm{~mm})$ at a density of $\sim 1 \times 10^{6}$ cells $/ \mathrm{ml}$ in $35 \times 10$ $\mathrm{mm}$ petri dishes (Falcon Labware, Becton Dickinson \& Co., Oxnard, CA). Upon reaching confluence (usually 3-4 d), the growth medium was replaced with a $0.2 \%$ FBS medium containing DMEM supplemented with $0.2 \%$ FBS and antibiotics (as above). For whole cell patch clamp recording, confluent cells were replated directly onto $35 \times 10$ $\mathrm{mm}$ petri dishes (Falcon) and incubated for $20-25 \mathrm{~h}$ in $0.2 \%$ FBS medium before insulin addition and whole cell recording.

Cell $\mathrm{Ca}^{2+}$ measurements. The effects of insulin on $\left[\mathrm{Ca}^{2+}\right]_{\mathrm{i}}$ responses to arginine vasopressin (AVP) were evaluated using both static (nonperfused) and constant perfusion systems. For static experiments, confluent cell monolayers were maintained in $0.2 \%$ FBS medium for 12 $24 \mathrm{~h}$ at $37^{\circ} \mathrm{C}, 100 \%$ humidity, and $5 \% \mathrm{CO}_{2}$. The medium was then replaced with $0.2 \%$ FBS medium containing various concentrations of human synthetic insulin $(0-100 \mathrm{mU} / \mathrm{ml})$. After $60 \mathrm{~min}$, fura 2-AM dissolved in DMSO was added to achieve final concentrations of $3 \mu \mathrm{M}$ fura 2-AM and $0.001 \%$ DMSO. Cells were incubated for a further 60 $\mathrm{min}$ in the presence of insulin and fura 2-AM. Cover slips containing the fura-loaded cells were rinsed twice at $37^{\circ} \mathrm{C}$ in a pH 7.4 physiological salt solution (PSS) containing (in mM) $145 \mathrm{NaCl}, 5 \mathrm{KCl}, 10$ Hepes, 1 $\mathrm{Mg}_{2} \mathrm{SO}_{4}, 0.5 \mathrm{Na}_{2} \mathrm{HPO}_{4}, 6$ glucose, and $1.5 \mathrm{CaCl}_{2}$. Deesterification of 
fura-2-AM to fura-2, the calcium-sensitive form of the compound, occurred during the 60 -min loading period and the subsequently described procedures, lasting $\sim 15 \mathrm{~min}$. Cover slips were then placed in a quartz nonfluorescing cuvette containing $3 \mathrm{ml}$ PSS maintained at $37^{\circ} \mathrm{C}$, and additions of AVP were carried out using a micropipette.

For constant perfusion experiments, cells were loaded with fura 2-AM (without insulin) as above. The cuvette was fitted with an acrylic perfusion apparatus through which media (maintained at $37^{\circ} \mathrm{C}$ and gassed with $95 \% \mathrm{O}_{2} / 5 \% \mathrm{CO}_{2}$ ) were constantly delivered by peristaltic pump at a rate of $6 \mathrm{ml} / \mathrm{min}$. The cuvette chamber was maintained at $37^{\circ} \mathrm{C}$ with a circulating water bath. Perfusion buffers (PSS, PSS + insulin, or Zero-Ca-PSS) and the corresponding AVP-containing perfusion buffers were added using a four-way stainless steel valve located upstream of the peristaltic pump. Fura-loaded cells were initially superfused with PSS for 10 min before any experimentation. $\mathrm{CaCl}_{2}$ was excluded in preparing Zero-Ca-PSS.

Fluorometric data were obtained using a dual excitation monochrometer spectrofluorometer (SPEX Fluorolog; Spex Industries, Inc., Edison, NJ). Excitation wavelengths of 340 and $380 \mathrm{~nm}$ and an emission wavelength of $505 \mathrm{~nm}$ were used with monochrometer slits set at 3 $\mathrm{nm}$. Calibration of the intracellular $\mathrm{Ca}^{2+}$ signal was accomplished using an $F_{\max }$ signal obtained with $30 \mu \mathrm{M} \mathrm{Br}-\mathrm{A} 23187$, and $\mathrm{F}_{\min }$ signal obtained with $0.5 \mathrm{mM} \mathrm{MnCl}{ }_{2}$ and $K_{\mathrm{d}}=224 \mathrm{nM}$. Br-A23187 is a nonfluorescent calcium ionophore that is also permeable to $\mathrm{Mn}^{2+}(14) . \mathrm{Mn}^{2+}$ is an effective quencher of fura-2 fluorescence (15). The value of $K_{d}$ is from Grynkiewicz et al. (15), as measured in a medium of $\sim 155 \mathrm{mM}$ ionic strength $(\mathrm{KCl} / \mathrm{NaCl} / \mathrm{K}-3-(4-\mathrm{Morpholino})$ propane sulfonic acid solution). These data were fitted to the formula of Grynkiewicz et al. (15) using software (DM3000CM; Spex Industries) designed for this purpose. Average calibrated relationships between $\left[\mathrm{Ca}^{2+}\right]_{i}$ and the 340:380 fluorescence ratio from several representative experiments were calculated. The relationship of $\left[\mathrm{Ca}^{2+}\right]_{i}$ to $340: 380$ fluorescence ratio from these prior calibrated experiments was applied to experiments in which a $7 \mathrm{r} 5$ cells were prepared and loaded with fura- 2 with identical procedures. Since such $\mathrm{Ca}^{2+}$ levels may be viewed as only "nominal," results were analyzed for each cover slip relative to its own baseline or initial response levels (where more than one response was elicited), as described in each figure caption.

Whole cell voltage clamp. A plexiglass insert with a central hole $\sim 1$ $\mathrm{cm}$ in diameter was clamped into the $35-\mathrm{mm}$ petri dish, forming a small subchamber $\sim 0.4 \mathrm{ml}$ in volume. Cells in the subchamber were constantly superfused at $\sim 6 \mathrm{ml} / \mathrm{min}$ with a $\mathrm{pH} 7.4$ solution containing (in $\mathrm{mM}$ ) $113 \mathrm{NaCl}, 4 \mathrm{KCl}, 2 \mathrm{MgCl}_{2}, 20 \mathrm{CaCl}_{2}$, and 10 Hepes. Whole cell currents were recorded using a patch clamp amplifier (8900; Dagan Corp., Minneapolis, MN), controlled by an A/D, D/A board (Labmaster TL-1 interface; Axon Instruments, Inc., Burlingame, CA) and PCLAMP software. Electrodes (nonheparinized hematocrit tubing; Fisher Scientific Co., Pittsburgh, PA) were pulled to bubble number 6 (16), polished to bubble number 3-4, and coated with Sylgard. Electrode solution contained (in mM) $120 \mathrm{KCl}, 10 \mathrm{~K}$-EGTA, 1.4 $\mathrm{MgCl}_{2}, 3.6 \mathrm{Mg}$-ATP, $1 \mathrm{Na}-\mathrm{GTP}$, and 10 Hepes (pH 7.2 adjusted with $\mathrm{KOH})$. Upon obtaining whole cell configuration, the cell was held at $-80 \mathrm{mV}$, and series resistance compensation was adjusted to a point just short of oscillation. Before testing the response of the cell to AVP, the response of the cell to changes in membrane potential was assessed, using either a pulse or ramp protocol (17). For the pulse protocol, the cell was clamped to various potentials at $10-\mathrm{mV}$ intervals from -80 $\mathrm{mV}$ to $+10 \mathrm{mV}$. Clamp pulses were 60 -ms duration administered at intervals of $1.2 \mathrm{~s}$. Linear leak and capacitative transients were subtracted using scaled hyperpolarizing pulses. For the ramp protocol, the response to a voltage ramp $(-80 \mathrm{mV}$ to $+10 \mathrm{mV}$ at $0.4 \mathrm{mV} / \mathrm{ms}$; digital resolution of this command voltage was $0.4 \mathrm{mV}$ ) was analyzed. Linear leak and holding current were removed by subtracting the linear current trend and average holding current between $-80 \mathrm{mV}$ and -70 $\mathrm{mV}$ from the entire current response. Only cells for which depolarization elicited at least $75 \mathrm{pA}$ inward current were evaluated to eliminate potentially nonviable cells. This eliminated 7 out of 20 control cells and 10 out of 24 insulin-treated cells (not significantly different, $P>0.05$, chi square test). To evaluate the response to AVP, holding current at $-80 \mathrm{mV}$ was recorded while the cell was superfused with $100 \mathrm{nM}$ AVP for $30 \mathrm{~s}$. AVP was added in line by a timer-controlled solenoid-operated valve.

Data were evaluated by chi square, Student's $t$ test, Mann-Whitney $\mathrm{U}$ test, one-way analysis of variance, two-way analysis of variance, and repeated measures analysis of variance (MANOVA, using software from SPSS Inc., Chicago, IL), as appropriate. Outliers were removed after identification by Dixon's gap test. Statistical tests were two-tailed except where stated. Population data are expressed as mean \pm SE. Relative potency of AVP was calculated using the parallel line assay described by Tallarida and Murray (18).

\section{Results}

AVP induces a transient rise in $\left[\mathrm{Ca}^{2+}\right]_{i}$. A7r5 VSMC had an average resting $\left[\mathrm{Ca}^{2+}\right]_{\mathrm{i}}$ of $136 \pm 16 \mathrm{nM}(n=85)$. AVP caused a transient rise in $\left[\mathrm{Ca}^{2+}\right]_{\mathrm{i}}$. In the nonperfused system (Fig. 1), the minimal level of AVP needed to elicit a response was $100 \mathrm{nM}$ (minimal level is defined here as the lowest [AVP] that produced a statistically significant increase in nominal $\left[\mathrm{Ca}^{2+}\right]_{\mathrm{i}}$ over resting $\left[\mathrm{Ca}^{2+}\right]_{\mathrm{i}}$. . Maximal response was elicited by $10 \mu \mathrm{M}$ AVP, which increased $\left[\mathrm{Ca}^{2+}\right]_{\mathrm{i}}$ to $1.3 \pm 0.4 \mu \mathrm{M}(n=13)$. In the perfused system VSMC were more sensitive to AVP. Pulses of $10 \mathrm{nM}$ AVP for $60 \mathrm{~s}$ elicited a rise in $\left[\mathrm{Ca}^{2+}\right]_{\mathrm{i}}$ from a resting level of $95 \pm 14 \mathrm{nM}$ to $213 \pm 60 \mathrm{nM}(n=25, P<0.05$, paired $t$ test). When 60 -s pulses of $10 \mathrm{nM}$ AVP were repeated in normal media once every $30 \mathrm{~min}$ (Fig. $2 \mathrm{~B}$, control curve), responses to AVP stayed relatively constant. When identical AVP pulses were given every $5 \mathrm{~min}$ (Fig. $3 \mathrm{~B}$, control curve), the response to AVP declined to $\sim 70 \%$ of the initial response, indicating that some desensitization occurs at shorter time intervals; however, subsequent responses remained relatively constant. Differences in AVP sensitivity of cells in the perfused and nonperfused systems may be due to a greater degree of desensitization occurring in the nonperfused system. Nevertheless, insulin-in-

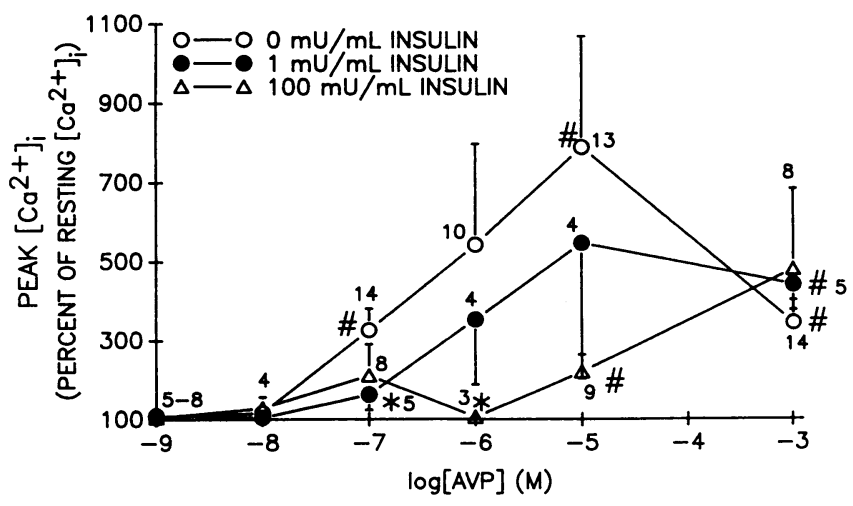

Figure 1. Effect of insulin on AVP-induced rises in $\left[\mathrm{Ca}^{2+}\right]_{i}$ in a7r5 vascular smooth muscle cells. Cells forming a confluent layer on cover slips were incubated for $2 \mathrm{~h}$ with insulin or control media, the last hour including $3 \mu \mathrm{M}$ fura-2-AM, and then placed just before observations in the spectrofluorometer cuvette. AVP was added ( $30 \mu \mathrm{l}$ of a concentrated solution to give the indicated final concentrations) 1 min after fluorescence measurement began. Peak $\left[\mathrm{Ca}^{2+}\right]_{i}$ responses to AVP were calculated for each slip as percent of resting $\left[\mathrm{Ca}^{2+}\right]_{\mathrm{i}}$ for that slip. Resting $\left[\mathrm{Ca}^{2+}\right]_{\mathrm{i}}$ averaged $153 \pm 21 \mathrm{nM}(n=60), 202 \pm 36 \mathrm{nM}$ $(n=17)$, and $177 \pm 24 \mathrm{nM}(n=40)$ for 0,1 , and $100 \mathrm{mU} / \mathrm{ml}$ insulin. *Significantly different $(P<0.05$, one-tailed $U$ test $)$ from control. "Significantly different from no increase in $\left[\mathrm{Ca}^{2+}\right]_{i}(100 \%$ is outside the $95 \%$ confidence limit of the mean). 

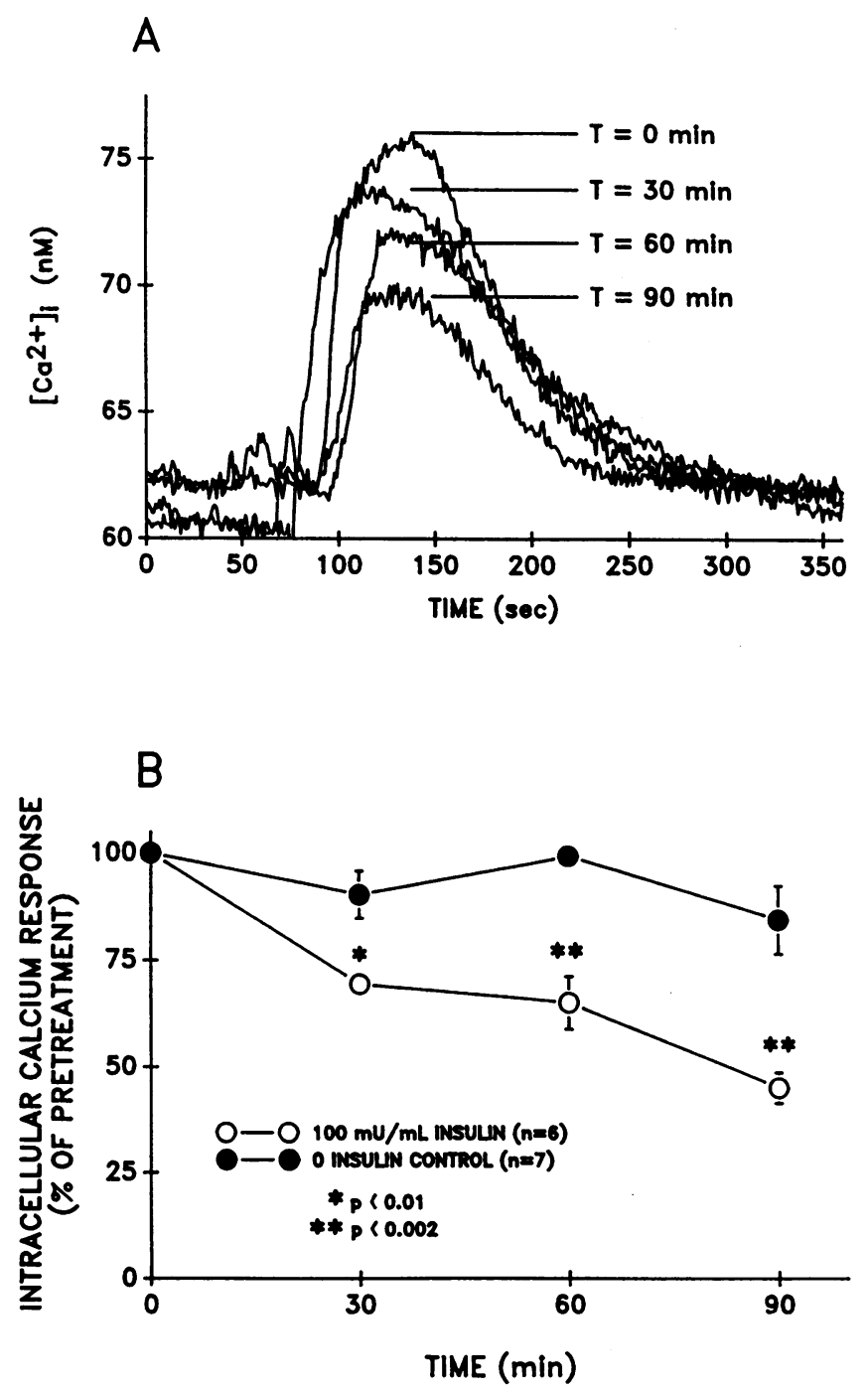

Figure 2. Time course of the effect of insulin on the AVP-induced rise in $\left[\mathrm{Ca}^{2+}\right]_{\mathrm{i}}$ in a7r5 VSMC. $(A)$ Representative fluorometric records from an experiment using the constant perfusion method. AVP (10 $\mathrm{nM}$ for $60 \mathrm{~s}$ ) was added before insulin perfusion and at 30,60 , and 90 min during insulin $(100 \mathrm{mU} / \mathrm{ml})$ perfusion. (B) Summary of data from 13 cover slips (6, insulin; 7 , no insulin). The AVP response was calculated as percent of the initial response. ${ }^{*} P<0.01$; ${ }^{* *} P<0.002$, MANOVA univariate comparisons to 0 insulin control. Considering all times together, the effect of insulin was significant $(P<0.01$, MANOVA).

duced changes in AVP responses, described below, occurred with both methods.

Insulin reduces $A V P$-induced rises in $\left[\mathrm{Ca}^{2+}\right]_{i}$. Fig. 1 also illustrates the effects of various concentrations of insulin on the dose-response curves for the AVP-induced rise in $\left[\mathrm{Ca}^{2+}\right]_{i}$ using the nonperfused method. A $2-\mathrm{h}$ exposure to insulin ( 0 [control], 1 , or $100 \mathrm{mU} / \mathrm{ml}$ ) before measurement of AVP responses resulted in a shift to the right of the dose-response curves. This is exemplified by an increase in the minimal concentration of AVP needed to produce a significant rise in $\left[\mathrm{Ca}^{2+}\right]_{i}$, from 100 $\mathrm{nM}$ for control to $10 \mu \mathrm{M}$ AVP after treatment with $100 \mathrm{mU} / \mathrm{ml}$ insulin. For $1 \mathrm{mU} / \mathrm{ml}$ insulin, the response to $10 \mathrm{nM}$ AVP was reduced $(P<0.05)$, and there was a trend for the AVP dose-response curve to be shifted to the right. Insulin decreased the relative potency of AVP by 16-fold and 220-fold, for 1 and 100 $\mathrm{mU} / \mathrm{ml}$ insulin, respectively.

To investigate the time course of the insulin effect on AVPinduced $\left[\mathrm{Ca}^{2+}\right]_{i}$ transients, the response to AVP was recorded from superfused fura-loaded cells before application of insulin, followed by AVP applications every $30 \mathrm{~min}$ in the presence of insulin. This was compared to control cells which were similarly stimulated with AVP every 30 min without the addition of insulin. A representative tracing is illustrated in Fig. $2 A$. Data from 13 cover slips are summarized in Fig. $2 B$. Insulin (100 $\mathrm{mU} / \mathrm{ml}$ ) reduced the response to $10 \mathrm{nM}$ AVP (MANOVA over all times, $P<0.01)$. The response was significantly reduced $(P$ $<0.01$, univariate comparison to 0 insulin control) by $31 \pm 3 \%$ within $30 \mathrm{~min}$, and decreased further with longer insulin exposure, by $35 \pm 6 \%$ at $60 \mathrm{~min}(P<0.002)$ and by $55 \pm 4 \%$ at $90 \mathrm{~min}$ $(P<0.002)$ after beginning insulin treatment. Insulin caused no significant changes in baseline $\left[\mathrm{Ca}^{2+}\right]_{\mathrm{i}}$ over the same time periods.

AVP response is mediated in part by extracellular $\mathrm{Ca}^{++}$. Removing $\mathrm{Ca}^{2+}$ from the perfusion buffer caused significant blunting of the AVP-induced rise in $\left[\mathrm{Ca}^{2+}\right]_{\mathrm{i}}$ as shown in the representative tracing in Fig. $3 A$. 1 min after beginning perfusion in zero-Ca-PSS the response to $10 \mathrm{nM} \mathrm{AVP}$ was only $37 \pm 14 \%$ of the response to similarly timed AVP applications in normal medium (MANOVA over all times, $P<0.01$; univariate comparison to PSS at $1 \mathrm{~min}, P<0.01$, one-tailed). The AVP-mediated rise in $\left[\mathrm{Ca}^{2+}\right]_{\mathrm{i}}$ remained depressed when tested at $6(P<0.05$, one-tailed $)$ and $11(P<0.01$, one-tailed $) \mathrm{min}$ after onset of $\mathrm{Ca}^{2+}$-free media (Fig. $3 B$ ). Within the time period examined, Zero-Ca-PSS caused no significant change in baseline $\left[\mathrm{Ca}^{2+}\right]_{\mathrm{i}}$.

Insulin reduces $A V P$-elicited current. AVP elicited a long lasting inward current at the holding potential of $-80 \mathrm{mV}$ (Fig. 4 A). Although AVP also elicited inward current in insulintreated cells, the peak current was markedly reduced compared to control cells. Peak current elicited by $100 \mathrm{nM}$ AVP was $-103 \pm 27 \mathrm{pA}$ in control cells $(n=12)$, whereas the peak AVP response in cells treated with insulin for $1.5 \mathrm{~h}$ with $100 \mathrm{mU} / \mathrm{ml}$ insulin was only $-37 \pm 15 \mathrm{pA}(n=14)(P<0.05)$ (Fig. $4 \mathrm{~B})$.

Insulin shifts the voltage dependence of voltage-dependent inward current. Depolarization elicited inward current in both insulin-treated and control cells (Fig. $5 \mathrm{~A}$ ). Although pipette and bath solutions were not chosen to isolate voltage-dependent $\mathrm{Ca}^{2+}$ current, the inward current so generated could nevertheless be completely eliminated by removal of extracellular $\mathrm{Ca}^{2+}$. In addition, this current could be increased by substituting barium for $\mathrm{Ca}^{2+}$ in the bathing solution (data not shown), indicative of voltage-dependent $\mathrm{Ca}^{2+}$ current. Current-voltage curves obtained using the pulse protocol are illustrated in Fig. 5. There was no significant difference between the peak inward current for control cells $(-525 \pm 292 \mathrm{pA}, n=9)$ and insulintreated cells $(-525 \pm 129 \mathrm{pA}, n=9)$; however, inward current began to activate at a more negative membrane potential in control cells than in insulin-treated cells. Two representative cells are shown in Fig. $5 \mathrm{~A}$. The peak current elicited by -40 $\mathrm{mV}$ in the control cell was approximately one-third as large as the maximum current that could be elicited in the same cell (the response to $-10 \mathrm{mV}$ ). In contrast, in the insulin-treated cell, depolarization to $-40 \mathrm{mV}$ elicited no voltage-dependent response, and a one-third maximal response was not attained until a depolarization of $-30 \mathrm{mV}$. Fig. $5 B$ shows average 

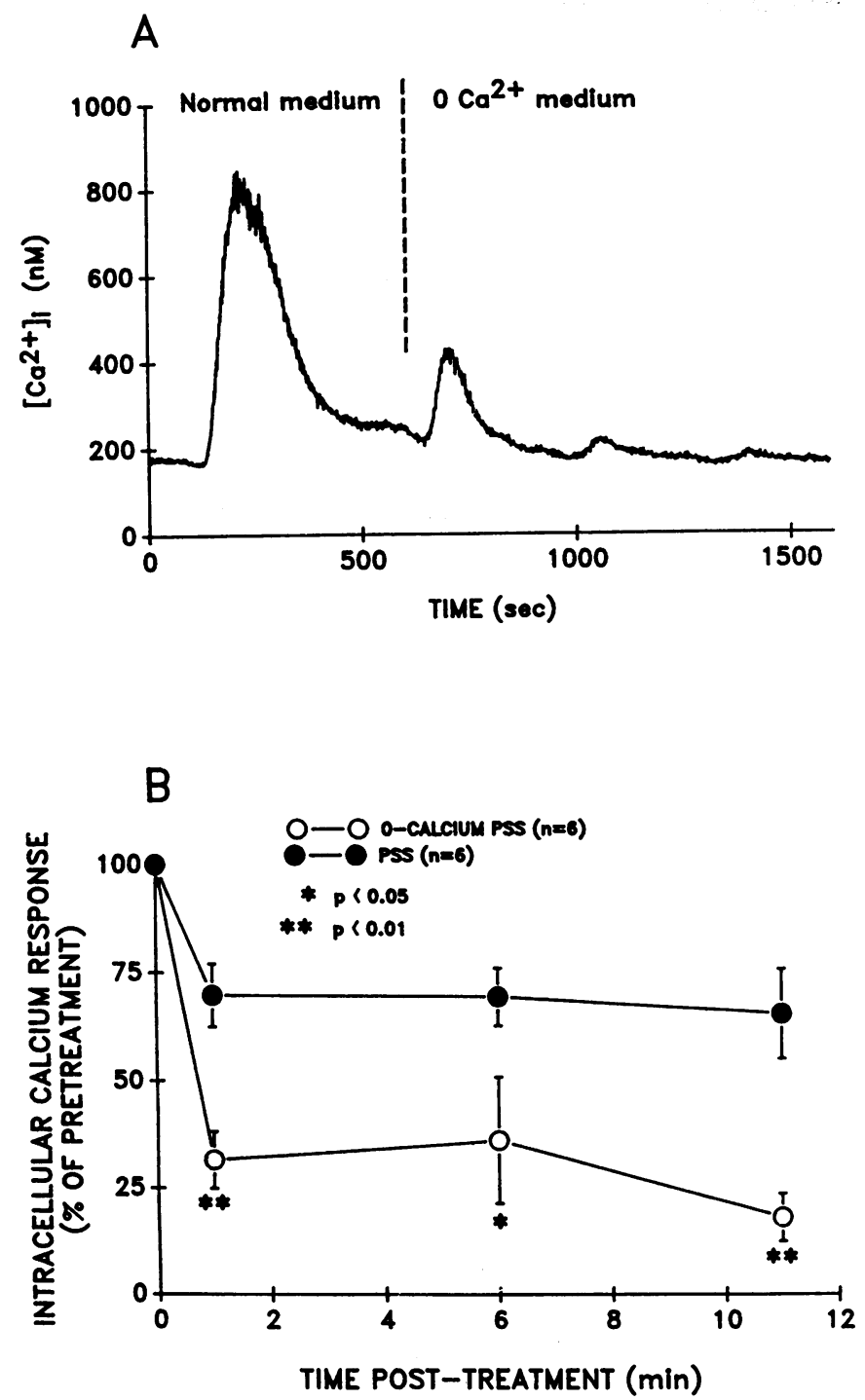

Figure 3. Effect of zero- $\mathrm{Ca}^{2+}$ medium on the AVP-induced rise in $\left[\mathrm{Ca}^{2+}\right]_{i}$ in a7r5 VSMC. $(A)$ Representative fluorometric record illustrating the response to $10 \mathrm{nM}$ AVP in the presence of extracellular calcium (Normal medium) and 1, 6, and 11 min after beginning perfusion without calcium ( $\left(\mathrm{Ca}^{2+}\right.$ medium). (B) Summary of AVP responses in zero calcium medium (six cover slips), expressed as percent of the initial response elicited in normal medium, compared to AVP responses elicited at similar intervals in normal medium (PSS) throughout (six cover slips). ${ }^{*} P<0.05 ;{ }^{* *} P<0.01$, MANOVA univariate comparisons to PSS (one-tailed). The effect of calcium-free medium over all times was significant (MANOVA, $P<0.01$ ).

current-voltage curves (normalized to maximum elicited current as described in the figure caption) for nine control and nine insulin-treated cells. The average current-voltage curve for insulin-treated cells is shifted to the right compared to control cells. The minimal depolarization that elicited a current of $20 \%$ of the maximal response was $-44 \pm 4 \mathrm{mV}$ in control cells and $-28 \pm 4 \mathrm{mV}$ in insulin-treated cells $(t$ test, $P<0.05)$. Furthermore, significantly more current was elicited in control cells than in insulin-treated cells at $-40 \mathrm{mV}$ and $-30 \mathrm{mV}$ (Fig. $5 \mathrm{~B}$ ). Considering the entire current-voltage curve in a repeated measures analysis of variance, insulin caused a significant change ( $P<0.05$, MANOVA, univariate mixed design test) in
A

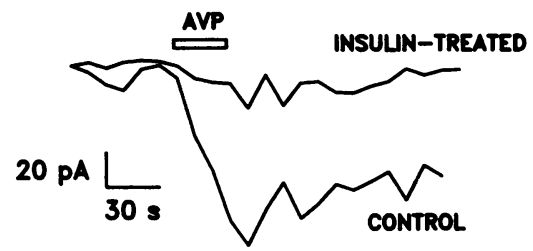

B

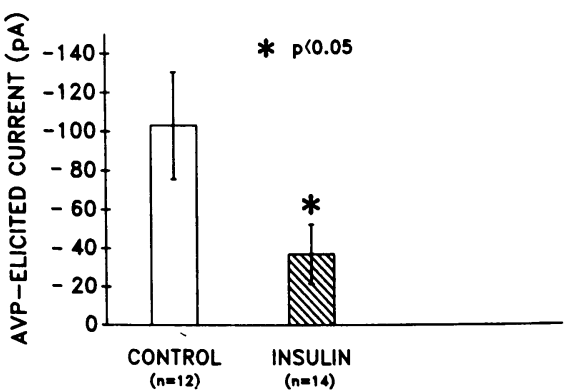

Figure 4. Effect of insulin on AVP-induced inward current. $(A)$ Representative recordings of the response to $100 \mathrm{nM} \mathrm{AVP}$ in control and insulin-treated cells $(100 \mathrm{mU} / \mathrm{ml}$ for $1.5 \mathrm{~h}$ preceding recording and $100 \mathrm{mU} / \mathrm{ml}$ in the recording medium). Illustrated recordings are of digitized data averaged for $20 \mathrm{~ms}$ periods every $10 \mathrm{~s}$. (B) Maximal AVP-induced inward current from 12 control and 14 insulin-treated cells. ${ }^{*} P<0.05, t$ test.

the response of the cells to voltage, with significant differences (univariate tests, $P<0.03$ ) at $-40 \mathrm{mV}$ and $-30 \mathrm{mV}$.

Average current-voltage curves obtained using the ramp protocol are illustrated in Fig. 6 . With its greater voltage resolution $(0.4 \mathrm{mV}$ per digital step compared to $10-\mathrm{mV}$ steps using the pulse method) the ramp command should give a better resolution of the membrane potential at which inward current begins to activate than does the pulse method. As with the pulse protocol, the membrane potential at which inward current began to activate in insulin-treated cells was shifted significantly to the right. A rise in inward current to $20 \%$ of the maximum response occurred with a minimal depolarization of $-43 \pm 3$ $\mathrm{mV}$ for control cells and $-27 \pm 3 \mathrm{mV}$ for insulin-treated cells $(P$ $<0.05$ ). Univariate analysis of variance comparing control and insulin-treated cells gave significance levels of $<0.04$ for all membrane potentials between $-54 \mathrm{mV}$ and $-25 \mathrm{mV}$.

\section{Discussion}

Data from this study clearly demonstrate that insulin attenuates the magnitude of both agonist (AVP)-induced $\left[\mathrm{Ca}^{2+}\right]_{\mathrm{i}}$ responses and agonist-elicited inward current in VSMC. Furthermore, insulin reduces the voltage sensitivity of a $\mathrm{Ca}^{2+}$-dependent, voltage-activated inward current. Thus, our previous observation of insulin-attenuation of vasoconstrictor responses (7) may be attributed, in part, to insulin blunting of $\left[\mathrm{Ca}^{2+}\right]_{i}$ responses to both receptor- and voltage-mediated stimuli. Observations of increased peripheral vascular resistance in human diabetic hypertensive states (4-6) and in both insulinopenic (9) and insulin-resistant (7) animal models may result from decreased insulin modulation of VSMC $\left[\mathrm{Ca}^{2+}\right]_{i}$ responses and thus enhanced $\left[\mathrm{Ca}^{2+}\right]_{i}$-mediated vascular contractility. Simi- 
A
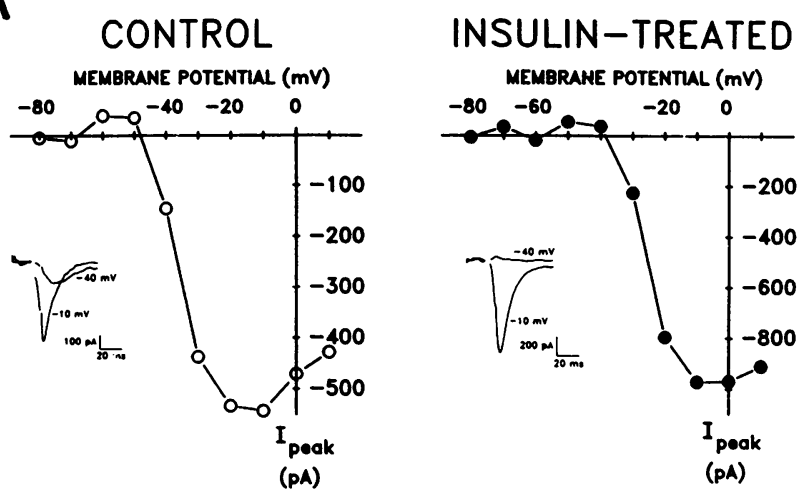

B

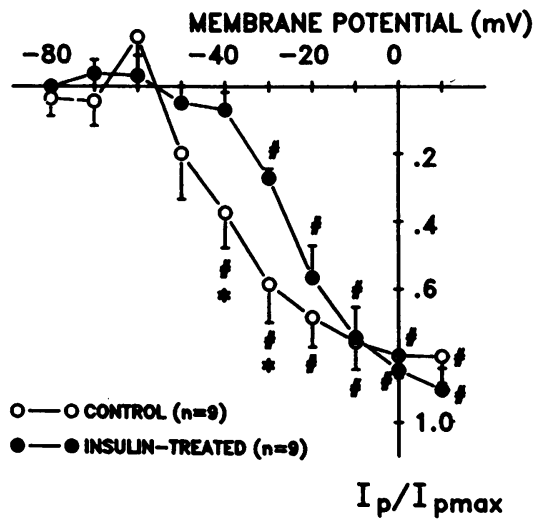

Figure 5. Effect of insulin on voltage-dependent inward current. $(A)$ Representative current-voltage curves for a control and an insulintreated cell $(100 \mathrm{mU} / \mathrm{ml}$ for $1.5 \mathrm{~h}$ preceding recording). Holding potential $=-80 \mathrm{mV}$. The graphs show peak inward current elicited by 60 -ms pulses to the indicated membrane potentials. Note particularly the membrane potential at which inward current began to activate. (Insets) Current recordings of the responses elicited by depolarization to $-40 \mathrm{mV}$ and $-10 \mathrm{mV}$ in the two representative cells. $(B)$ Summary of current-voltage curves from 18 cells ( 9 insulin treated, 9 control). Currents were normalized by dividing each cell's current-voltage curve by its maximum elicited current, to reduce the variance between cells caused by differences in cell size, channel density, etc. Normalized responses at each clamp potential were then averaged for all cells in each treatment group. ${ }^{*} P<0.03$, MANOVA univariate tests comparing normalized control response to normalized insulintreated response at each depolarization. All nonsignificant points had $P>0.05$. "Significantly different from no response ( 0 is outside the $95 \%$ confidence limit of the mean). Considering all responses together in a repeated measures MANOVA, the significance level of the insulin by voltage interaction was $<0.05$.

larly, Lucas et al. (19) have suggested that hypertension associated with obesity may be related to the tendency of overweight people to have increased insulin resistance.

VSMC $\left[\mathrm{Ca}^{2+}\right]_{\mathrm{i}}$ responses to AVP, upon which this study focuses, can clearly play a role in regulating peripheral vascular resistance. Intravenous infusions of AVP which elevate plasma concentrations by $<5 \mathrm{pg} / \mathrm{ml}$ significantly increase total peripheral resistance in conscious dogs (20). AVP causes a two to sixfold increase in VSMC $\left[\mathrm{Ca}^{2+}\right]_{i}$ at concentrations of peptide that yield maximal vascular responses (21). Since the increases

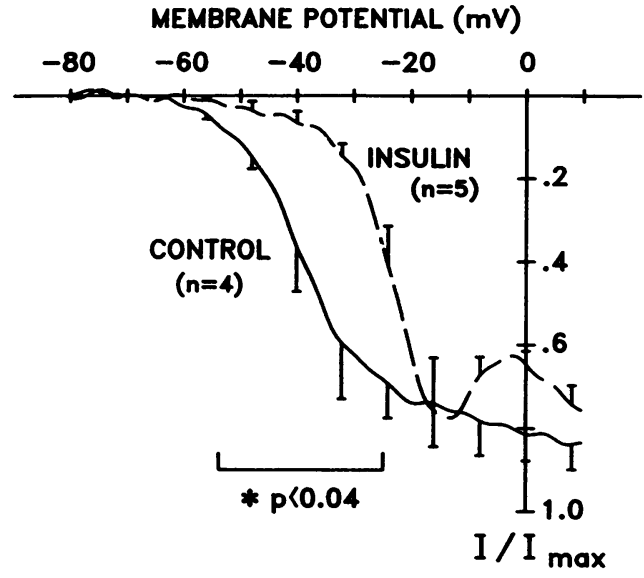

Figure 6. Effect of insulin on the current elicited by a voltage ramp. Summary of data from four control and five insulin-treated cells. After subtracting linear current trend and baseline as described in Methods, currents were normalized by dividing by the maximum elicited current. Normalized responses were then averaged for all cells in each treatment group. The graph shows the mean (solid line) and SE (oppositely directed error bars for every 10 th sample of the two curves). The starred region shows the contiguous region where $P$ $<0.04$ for univariate tests comparing control cells to insulin-treated cells.

in $\left[\mathrm{Ca}^{2+}\right]_{\mathrm{i}}$ induced by AVP in this and previous studies $(20,21)$ are similar to the range of $\left[\mathrm{Ca}^{2+}\right]_{i}$ that regulates VSM tone (22), it is reasonable to suggest that AVP is an important hormone regulating peripheral vascular resistance. Furthermore, since physiological levels of AVP are less than the concentration that produces maximal responses, shifts in the dose-response curve to the right or left even without a change in maximal response would have significant effects on physiological function.

The AVP-induced rise in $\left[\mathrm{Ca}^{2+}\right]_{i}$ is mediated by the $\mathrm{V}_{1}$ receptor subclass, which activates phosphoinositol breakdown. The rise in $\left[\mathrm{Ca}^{2+}\right]_{\mathrm{i}}$ is due to both release from the intracellular pool induced by inositol 1,4,5-trisphosphate as well as influx from the extracellular space modulated by diacylglycerol (2325). Upon demonstrating that insulin significantly reduced the AVP-induced rise in $\left[\mathrm{Ca}^{2+}\right]_{\mathrm{i}}$ (Figs. 1 and 2), this investigation then focused on the component of the response dependent upon extracellular $\mathrm{Ca}^{2+}$. The results indicate that insulin acts to modulate $\mathrm{Ca}^{2+}$ influx from the extracellular pool. Within one minute of removing extracellular $\mathrm{Ca}^{2+}$, the response to AVP was reduced to only $37 \%$ of its prior level. Nabika et al. (21) and Capponi et al. (26) similarly demonstrated a dependence of AVP-stimulated increases in $\left[\mathrm{Ca}^{2+}\right]_{\mathbf{i}}$ in VSMC on extracellular $\mathrm{Ca}^{2+}$. Removal of extracellular $\mathrm{Ca}^{2+}$ in the experiments of $\mathrm{Na}-$ bika et al. (21) reduced responses to $100 \mathrm{nM}$ AVP without affecting responses to $100 \mathrm{nM}$ angiotensin II, implying that the effect of removing extracellular $\mathrm{Ca}^{2+}$ was not due to depleting internal $\mathrm{Ca}^{2+}$ stores which are still available for release by angiotensin II. The interpretation that the decrease represents loss of a transmembrane AVP-induced flux is further supported by measurement of whole cell currents. Van Renterghem et al. (27) demonstrated that AVP activates a nonspecific cation channel in a $7 r 5$ cells that induces inward current similar to our observations (Fig. 4). Furthermore, we have confirmed that AVP can induce inward current in a $\mathrm{Na}^{+}$-free/high $\mathrm{Ca}^{2+}$ medium (data not shown), indicating that a portion of AVP-in- 
duced increase in $\left[\mathrm{Ca}^{2+}\right]_{\mathrm{i}}$ is due to $\mathrm{Ca}^{2+}$ influx via a receptoroperated channel. Since insulin substantially reduces this nonspecific cation current (Fig. 4), at least a portion of insulin attenuation of VSMC $\left[\mathrm{Ca}^{2+}\right]_{i}$ responses to AVP may be attributed to reduced $\mathrm{Ca}^{2+}$ influx through receptor-operated channels. Whether this is due to a downregulation of AVP receptors, a change in coupling of the AVP receptor to intracellular mediators, or a reduction in the response of channels activated by them is a question for future research.

Data from this study also show that insulin causes a rightward shift of the current-voltage curves for overall current in a7r5 VSMC without changing the maximum current elicited. The shift in the voltage dependence without a change in peak current accords well with previous observations on muscle strips that the effect of insulin is to shift dose-response curves to the right without changing the maximum response (7). A7r5 cells have previously been shown to have voltage-dependent $\mathrm{Ca}^{2+}$ channels $(27,28)$. Although recording conditions in our study were not chosen to isolate $\mathrm{Ca}^{2+}$ current, the inward current is $\mathrm{Ca}^{2+}$ dependent (28). The shift in the total current may result either from a decrease in the activation of $\mathrm{Ca}^{2+}$ current or an increase in activation of $\mathrm{K}^{+}$current between -25 and $-45 \mathrm{mV}$, where the difference between insulin-treated and control cells is most evident. In unclamped cells, both phenomena (reduced $\mathrm{Ca}^{2+}$ activation or increased $\mathrm{K}^{+}$activation) would elicit comparable effects on net $\mathrm{Ca}^{2+}$ influx. Clearly, reduced activation of $\mathrm{Ca}^{2+}$ channels will reduce $\mathrm{Ca}^{2+}$ influx; similarly, increased activation of $\mathrm{K}^{+}$channels inhibits depolarization and would thereby reduce activation of voltage-dependent $\mathrm{Ca}^{2+}$ channels. Our observed change in the voltage sensitivity of $\mathrm{Ca}^{2+}$ current in response to insulin in VSMC is similar to observations of $\mathrm{Wu}$ and Zierler (12) on the effect of insulin on $\mathrm{Ca}^{2+}$ current in skeletal muscle myoballs. Wu and Zierler (12) illustrated a rightward shift in the membrane potential at which transient $\mathrm{Ca}^{2+}$ current was activated; however, in contrast to data reported here, they also observed a decrease in maximal current. This discrepancy may result from differences in responses to insulin between skeletal and VSMC.

It is likely that insulin-induced attenuation of vasoconstriction is not entirely attributable to the reductions in voltage- and receptor-mediated $\mathrm{Ca}^{2+}$ current observed in this study. The inositol trisphosphate-mediated release of $\mathrm{Ca}^{2+}$ from intracellular stores may also be modulated by insulin. Possible targets could include the release mechanism itself or the mechanisms regulating the total $\left[\mathrm{Ca}^{2+}\right]_{\mathrm{i}}$ stores. We have also recently found insulin to stimulate VSMC $\mathrm{Ca}^{2+}$ efflux in a dose-dependent fashion (13). Insulin regulation of VSMC $\mathrm{Ca}^{2+}$ efflux required exposure to insulin for $>60 \mathrm{~min}$. Furthermore, insulin effects on $\mathrm{Ca}^{2+}$ efflux required new protein synthesis, as evidenced by blockade of this effect by cyclohexamide (13). In our study insulin effects on AVP-induced increases of $\left[\mathrm{Ca}^{2+}\right]_{i}$ were observed within $30 \mathrm{~min}$ of insulin treatment. Wu and Zierler (12) observed insulin-induced reductions in $\mathrm{Ca}^{2+}$ current as early as 5 min after initiating insulin treatment. Thus, sustained insulin attenuation of $\mathrm{Ca}^{2+}$ responses may result from both an early blunting of $\mathrm{Ca}^{2+}$ influx and a slower regulation of $\mathrm{Ca}^{2+}$ efflux which is dependent upon new protein synthesis.

A large number of studies have shown that hypertension is associated with hyperinsulinemia $(19,29)$. One interpretation of this association is that insulin causes the hypertension. Suggested mechanisms include a direct sodium-retaining action of insulin on the kidney $(30,31)$ and an insulin-stimulated rise in sympathetic nervous system activity $(32,33)$. An alternative view $(34,35)$ is that the primary anomaly is the development of insulin resistance, in both the metabolic and vasoconstriction attenuating functions of insulin. From this perspective, loss of attenuation of vasoconstrictive responses leads to increased peripheral resistance resulting in hypertension; whereas, the increased insulin levels are a secondary response to inadequate regulation of blood glucose in the insulin-resistant state. Hypertension associated with type II diabetes may be attributed to a similar mechanism. Insulin attenuation of VSMC Ca ${ }^{2+}$ responses, as shown in our study, supports the second perspective. It is possible, however, that hyperinsulinemic effects on some tissues (kidney, sympathetic nervous system) may act synergistically with insulin-resistance effects on other tissues (vascular smooth muscle) to produce the hypertensive state.

In summary, data presented here indicate that $\mathrm{Ca}^{2+}$ transport in VSMC is modulated, in part, by insulin. Insulin shifts dose-response curves to the right, thereby attenuating VSMC $\left[\mathrm{Ca}^{2+}\right]_{i}$ responses to physiological levels of AVP. Insulin reduces $\mathrm{Ca}^{2+}$ influx by both receptor (AVP) and voltage operated channels. Such insulin regulation of smooth muscle function may be lost in both insulin-resistant and insulinopenic states. It should be pointed out, however, that the results presented here were produced by short-term application of high doses of insulin to an in vitro VSMC preparation, and chronic changes in insulin or insulin resistance in vivo may produce different effects. Nevertheless, our results suggest the possibility that loss of insulin regulation of agonist-induced responses in smooth muscle may be one mechanism underlying the development of hypertension associated with diabetes.

\section{Acknowledgments}

The authors would like to thank M. Kruger and J. Ager for assistance with statistical analysis. We would also like to thank Ms. Doris King, Ms. Sandy Howells, and Ms. Linda McCraw for their assistance in preparing this manuscript.

This research was supported, in part, by Veterans Administration Medical Research funds (M. B. Zemel and J. R. Sowers) and National Institutes of Health grants RR-08167 (J. L. Ram) and HD-24497 (J. R. Sowers).

\section{References}

1. Ferrannini, E., G. Buzzigoli, R. Bonadonna, M. A. Giorico, M. Oleggini, L. Graziadei, R. Pedrinelli, L. Brandi, and S. Bevilacqua. 1987. Insulin resistance in essential hypertension. N. Engl. J. Med. 317:350-357.

2. Shen, D.-C., S.-M. Shieh, M. Fuh, D.-A. Wu, Y.-D. I. Chen, and G. M. Reaven. 1988. Resistance to insulin-stimulated glucose uptake in patients with hypertension. J. Clin. Endocrinol. \& Metab. 66:580-583.

3. Swislocki, A. L. M., B. B. Hoffman, and G. M. Reaven. 1989. Insulin resistance, glucose intolerance, and hyperinsulinemia in patients with hypertension. Am. J. Hypertens. 2:419-423.

4. Levy, J., M. B. Zemel, and J. R. Sowers. 1989. Role of cellular calcium metabolism in abnormal glucose metabolism and diabetic hypertension. $\mathrm{Am}$. J. Med. 87 (Suppl. 6A):7S-16S.

5. O'Hare, J. A., J. B. Ferriss, D. Brady, B. Twomey, and D. J. O'Sullivan. 1985. Exchangeable sodium and renin in hypertensive diabetic patients with and without nephropathy. Hypertension (Dallas). 7(Suppl. 2):II43-II48.

6. Weidman, P., C. Beretta-Picolli, G. Keusch, Z. Gluck, M. Mujagic, M. Grimm, A. Meier, and W. H. Ziegler. 1979. Sodium-volume factor, cardiovascular reactivity and hypotensive mechanism of diuretic therapy in mild hypertension associated with diabetes mellitus. Am. J. Med. 67:779-784.

7. Zemel, M. B., S. Reddy, S. E. Shehin, W. Lockette, and J. R. Sowers. 1990. Vascular reactivity in Zucker obese rats: role of insulin resistance. J. Vasc. Med. Biol. 2:82-85.

8. Yagi, S., S. Takata, H. Kiyokawa, M. Yamamoto, Y. Noto, T. Ikeda, and N. Hattori. 1988. Effects of insulin on vasoconstrictive responses to norepineph- 
rine and angiotensin II in rabbit femoral artery and vein. Diabetes. 37:1064 1067.

9. Reddy, S., S. Shehin, J. R. Sowers, G. Dardas, and M. Zemel. $1990 .{ }^{45} \mathrm{Ca}$ flux and blood pressure regulation in streptozotocin-induced diabetic rats. $J$. Vasc. Med. Biol. 2:47-51.

10. Shehin, S. E., J. R. Sowers, and M. B. Zemel. 1989. Impaired vascular smooth muscle ${ }^{45} \mathrm{Ca}$ efflux and hypertension in Zucker obese rats. J. Vasc. Med. Biol. 1:278-282.

11. Khalil, R. A., N. J. Lodge, K. Saida, C. H. Gelband, and C. van Breemen. 1990. Calcium mobilization in vascular smooth muscle and its relevance to the etiology of hypertension. In Hypertension: Pathophysiology, Diagnosis, and Management. J. H. Laragh and B. M. Brenner, editors. Raven Press, Ltd., New York. 547-563.

12. Wu, F.-S., and K. Zierler. 1989. Calcium currents in rat myoballs and their inhibition by insulin. Endocrinology. 125:2563-2572

13. Johnson, B. A. B., K. Patel, J. R. Sowers, and M. B. Zemel. 1990. Possible mechanisms of insulin attenuation of vascular reactivity. FASEB (Fed. Am. Soc Exp. J. Biol.) 4:A857.

14. Deber, C. M., J. Tom-Kun, E. Mack, and S. Grinstein. 1985. BromoA23187: a non-fluorescent calcium ionophore for use with fluorescent probes. Anal. Biochem. 146:349-352.

15. Grynkiewicz, G., M. Poenie, and R. Y. Tsien. 1985. A new generation of $\mathrm{Ca}^{2+}$ indicators with greatly improved fluorescence properties. J. Biol. Chem. 260:3440-3450.

16. Corey, D., and C. S. Stevens. 1985. Science and technology of patch-recording electrodes. In Single Channel Recording. B. Sakman and E. Neher, editors. Plenum Press, New York. 53-68.

17. Ram, J. L., F. Zhang, and L.-X. Liu. 1991. Contraction, serotonin-elicited modulation, and membrane currents of dissociated fibers of Aplysia buccal muscle. Biol. Bull. (Woods Hole). 180:276-283.

18. Tallarida, R. J., and R. B. Murray. 1981. Manual of Pharmacologic Calculations with Computer Programs. Springer-Verlag New York Inc. 21-24.

19. Lucas, C. P., J. A. Estigarribia, L. L. Darga, and G. M. Reaven. 1985. Insulin and blood pressure in obesity. Hypertension (Dallas). 7:702-706.

20. Montani, J. P., J. F. Liard, J. Schoun, and J. Mohring. 1980. Hemodynamic effects of exogenous and endogenous vasopressin at low plasma concentrations in conscious dogs. Circ. Res. 47:346-355.

21. Nabika, T., P. A. Velletri, W. Lovenberg, and M. A. Beaven. 1985. Increase in cytosolic calcium and phosphoinositide metabolism induced by angiotensin II and [Arg]vasopressin in vascular smooth muscle cells. J. Biol. Chem. $260: 4661-4670$
22. Blaustein, M. P. 1977. Sodium ions, calcium ions, blood pressure regulation, and hypertension: a reassessment and a hypothesis. Am. J. Physiol. 232: $\mathrm{Cl67}-\mathrm{C173}$

23. Litosch, I., S.-H. Lin, and J. N. Fain. 1983. Rapid changes in hepatocyte phosphoinositides induced by vasopressin. J. Biol. Chem. 258:13727-13732.

24. Thomas, A. P., J. Alexander, and J. R. Williamson. 1984. Relationship between inositol polyphosphate production and the increase in cytosolic free $\mathrm{Ca}^{2+}$ induced by vasopressin in isolated hepatocytes. J. Biol. Chem. 259:5574-5584.

25. Missiaen, L., I. Declerck, G. Droogmans, L. Plessers, H. DeSmedt, L. Raeymaekers, and R. Casteels. 1990. Agonist-dependent $\mathrm{Ca}^{2+}$ and $\mathrm{Mn}^{2+}$ entry dependent on state of filling of $\mathrm{Ca}^{2+}$ stores in aortic smooth muscle cells of the rat. J. Physiol. (Lond.). 427:171-186.

26. Capponi, A. M., P. D. Lew, and M. B. Vallotton. 1985. Cytosolic free calcium levels in monolayers of cultured rat aortic smooth muscle cells. Effects of angiotensin II and vasopressin. J. Biol. Chem. 260:7836-7842.

27. Van Renterghem, C., G. Romey, and M. Lazdunski. 1988. Vasopressin modulates the spontaneous electrical activity in aortic cells (line A7r5) by acting on three different types of ionic channels. Proc. Nat. Acad. Sci. USA. 85:93659369.

28. Fish, R. D., G. Sperti, W. S. Colucci, and D. E. Clapham. 1988. Phorbo ester increases the dihydropyridine-sensitive calcium conductance in a vascular smooth muscle cell line. Circ. Res. 62:1049-1054.

29. Christlieb, A. R., A. S. Krolewski, J. H. Warram, and J. S. Soeldner. 1985 Is insulin the link between hypertension and obesity? Hypertension (Dallas). 7 (Suppl. II):II54-II57.

30. DeFronzo, R. A. 1981. The effect of insulin on renal sodium metabolism Diabetologia. 21:165-171.

31. DeFronzo, R. A., M. Goldberg, and Z. S. Agus. 1976. The effects of glucose and insulin on renal electrolyte transport. J. Clin. Invest. 58:83-90.

32. Rowe, J. W., J. B. Young, K. L. Minaker, A. L. Stevens, J. Pallotta, and L. Landsberg. 1981. Effect of insulin and glucose infusions on sympathetic nervous system activity in normal man. Diabetes. 30:219-225.

33. Young, J. B., and L. Landsberg. 1982. Diet-induced changes in sympathetic nervous system activity: possible implications for obesity and hypertension. J. Chron. Dis. 35:879-886

34. Sowers, J. R. 1990. Insulin resistance and hypertension. Mol. Cell. Endocrinol. 74:C87-C89.

35. Falkner, B., S. Hulman, J. Tannenbaum, and H. Kushner. 1990. Insulin resistance and blood pressure in young black men. Hypertension (Dallas). 16:706-711. 